Goldschmidt 2021 Abstract

https://doi.org/10.7185/gold2021.5406

\section{Trace element composition of scheelite as an exploration tool for gold and tungsten deposits}

ANA CAROLINA R MIRANDA ${ }^{1}$, GEORGES BEAUDOIN ${ }^{1}$, BERTRAND ROTTIER $^{1}$, JAN PASAVA ${ }^{2}$, JAN MALEC ${ }^{2}$ AND PETR BOHDÁLEK ${ }^{2}$

${ }^{1}$ Université Laval

${ }^{2}$ Czech Geological Survey

Presenting Author: acrmiranda1@gmail.com

Scheelite is a tungsten ore mineral and has been proposed as an efficient indicator mineral for targeting tungsten and gold deposits $[1,2]$. It commonly occurs in skarn, stockwork, greisen, $\mathrm{Sn}-\mathrm{W}$ porphyry, reduced intrusion-related gold systems (RIRGS) and orogenic gold deposits. Scheelite major and trace element composition vary as a function of the origin, composition, and physicochemical conditions of the mineralizing fluids [3,4,5].

Trace element composition of scheelite from 11 oxidized and reduced skarns, 3 greisen, 7 RIRGS, 1 metamorphosed intrusionrelated (Felbertal), 2 porphyry and 1 orogenic deposits were acquired by LA-ICP-MS. Our results ( $\mathrm{n}=453$ analyses) combined with literature data ( $\mathrm{n}=682$ analyses) were investigated using partial least squares-discriminant analysis (PLS-DA) to establish discriminating chemical criteria for scheelite from different deposit types, and thus supporting the application of scheelite as an efficient indicator mineral for mineral exploration targeting.

The PLS-DA results show that scheelite from orogenic gold deposits can be distinguished from those of intrusion-related deposits due to higher $\mathrm{Sr}, \mathrm{Pb}, \mathrm{Ba}$ and REE, and lower $\mathrm{Mo}, \mathrm{Ta}$ and $\mathrm{Nb}$ concentrations (Fig. 1). Scheelite from RIRGS is chemically similar to those from reduced skarns, which may reflect similar magmatic origin and the reduced character of the mineralizing fluids. Scheelite from greisen and oxidized skarn deposits can be discriminated from the remaining deposits due to their higher concentrations of $\mathrm{Mn}$ (greisen), and Mo and $\mathrm{Ti}$ (oxidized skarns).

Scheelite from Felbertal (Austria), an intrusion-related W deposit that underwent regional metamorphic recrystallization [6], plots at the magmatic-hydrothermal side and is chemically similar to scheelite from porphyry and reduced skarns. Our results show that scheelite chemistry is a function of the physical and chemical characteristics of the mineralizing fluids inherent to each deposit type and thus scheelite can be used as an efficient targeting tool for gold and tungsten deposits.

[1] McClenaghan et al (2017) GEOCHEM-EXPLOR ENV A 17, 297-313.

[2] Manéglia et al (2018) GEOCHEM-EXPLOR ENV A 18, 241-251.

[3] Poulin et al (2018) Can Mineral 56, 265-302.

[4] Sciuba et al (2020) Mineralium Deposita 55, 1149-1172.

[5] Miranda and Beaudoin (2020) GSA 52, No 6.

[6] Kozlik et al (2016) Miner Petrol 110, 11-27
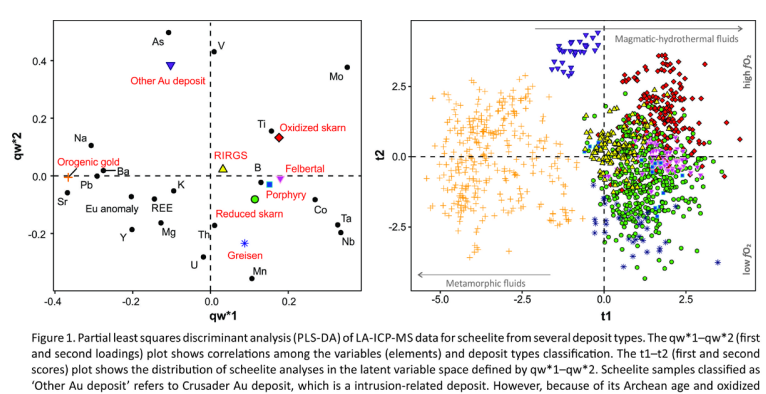

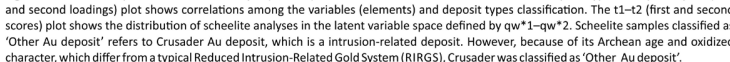

